The 'Employment First' Welfare State: lessons from the New Deal for Young People Dan Finn, Professor of Social Policy, University of Portsmouth*

* Please note that between 1997 and 2001 the author was a Special Adviser to the national New Deal Task Force and the House of Commons Education and Employment Select Committee. 


\title{
The 'Employment First' Welfare State: lessons from the New Deal for Young People
}

\begin{abstract}
New Labour is introducing an 'employment first' welfare state. A new Jobcentre Plus Agency is transforming the passive culture of the benefit system and creating more explicit links between individual behaviour and engagement with labour market programmes. The New Deal for Young People (NDYP) has been at the forefront of these changes. This article reports on the findings from four independent case studies to explore how the NDYP is being implemented at the front line and how this 'welfare to work' regime has changed young people's experience of the welfare state. It concludes that the programme is not the monolithic instrument of social control, suggested by many of its social policy critics, but a complex and sometimes contradictory synthesis of employment assistance and 'pressure' which has made real progress in improving front line services and getting young long term unemployed people into work.
\end{abstract}

\section{Introduction}

Britain's Labour Government is creating an 'employment first' welfare state (DfEE, 2001). The aim is to prioritise employment assistance and transform the 'passive' culture of the benefit system. A new agenda of 'rights and responsibilities' is creating more explicit links between individual behaviour, benefit entitlement and engagement with the labour market.

The first phase of welfare reform, from 1997 until 2001, witnessed the introduction of New Deal employment programmes alongside tax and benefit changes aimed at 'making work pay'. A second phase was outlined first in a 2001 Green Paper which directly linked welfare reform with full employment. In a foreword the Prime Minister suggested there was now an "historic opportunity" to build on "economic stability and reform of the welfare state" to secure "employment opportunities for all” - New Labour's 'modern' definition of full employment (DfEE, 2001, p.vi). Following its subsequent election victory the Government has set ambitious targets to increase employment rates, reduce child poverty and tackle social exclusion. Key policy developments include the extension of tax credits to the low paid, the intensification of New Deal programmes, and the introduction of mandatory 'work focused interviews' for all working age benefit claimants. Welfare reform also is being accompanied by major institutional change. A Department of Work and Pensions has been created and the Employment Service (ES) and Benefits Agency (BA) have been replaced by 'Jobcentre Plus'. The aim is that by 2005 the new agency will have integrated the work of nearly 90,000 staff employed in 1,500 offices bringing together job search support and benefit payments for over six million people.

This agenda is formidable. The intention is to embed a new 'rights and responsibilities' culture through the transformation of the primarily 'passive' support offered by the postwar welfare state into a more 'active' combination of responsibilities and services thought relevant to the labour markets and social conditions of the new century. Jobcentre 
Plus will be at the forefront of this cultural change and will "enshrine the principle that everyone has an obligation to help themselves, through work wherever possible". In return, Government has "an equal responsibility" to provide work related assistance for those "who can" as well as ensuring "greater security for those who cannot" (HMT, 2001, p. iv).

This transformation of the British welfare state is contextualised within an international process of reform actively promoted both through the 'Jobs Strategy' of the OECD (1994) and the 'Employment Strategy' of the European Union (EC, 2000). Each member-state may follow its own path to reform but the common aims of the emergent 'welfare to work' regimes are to reduce unemployment and 'welfare dependency' by 'activating' benefit systems, improving employability, and reinforcing work incentives.

New social theories have been generated to analyse and to influence the direction of these 'workfare’ regimes (Jessop, 1994; Giddens, 1998; Green, 1999; Peck, 2001). One of the few things these writers have in common is that they seek to articulate, or identify, the new, and often very different, ways in which long standing traditional objectives are being recast in modern employment assistance and benefit payment systems. They all recognise that the modern welfare state continues to be the subject of intense political debate and struggle, although some theorists too quickly assume that social welfare systems are being subordinated to the imperatives of capital accumulation. The point is that as in the past the emergent British 'workfare settlement' is not a monolithic instrument of social control, but a complex and sometimes contradictory political and administrative synthesis which is intended to:

- help maintain labour market discipline and efficiency;

- provide cash income for those without work and their children;

- pay benefits accurately, but enforce changing eligibility rules and discourage fraud; and

- improve the employability of disadvantaged groups, such as the long term unemployed or people with disabilities.

This article aims to assess how this combination of objectives is being delivered at the 'front line', through the New Deal for Young People (NDYP), and to draw out some implications for the emerging British 'employment first' welfare state. It draws on the findings from four independent case studies carried out in five cities between 1999 and 2002, with supplementation from official evaluation reports. It explores how 'welfare to work' or 'workfare' is changing young people's experience of the welfare state.

The NDYP has been chosen because it has been the 'flagship' of New Labour's welfare to work strategy and was fully implemented in April 1998. It has also been subject to much political criticism. In a succession of journal articles academics, and others, have also assessed the merits of the programme, identified significant weaknesses, and found it wanting. The authors have often concluded that NDYP is in essence part of a coercive regime designed to make access to benefits more difficult and to increase competition for jobs at the lowest end of the labour market (see, for example, Tonge, 1999; Jeffs and 
Spence, 2000; GMLPU, 2001; Gray, 2001). This article suggests that the reality of the new welfare state is more complex. There are mixed messages at the front line, where positive assistance coexists with pressure, and where a new generation of personal advisers are struggling to translate New Labour rhetoric into practice.

\section{New Labour and Full Employment}

In the 1990s, the leadership of the Labour Party transformed their approach to unemployment and the welfare state. Although New Labour abandoned Keynsian demand management, they rejected the neo-liberal view of the Conservatives which, in the famous words of one Chancellor of the Exchequer, suggested that unemployment was "a price worth paying" to control inflation and stimulate economic growth (Hansard, col. 413, 16 May 1991). Instead New Labour turned to the work of economists that challenged the view that the 'NAIRU' (the non-accelerating inflation rate of unemployment) had to be as high as it was in the UK. The new approach suggested that 'supply-side' measures such as investment in human capital and labour market programmes could lower the NAIRU. The stricter job search regime introduced by the Conservatives was to be retained but it was to be supplemented by a minimum wage and a 'New Deal' for the long term unemployed. This 'synthesis' would require individuals to compete for and obtain jobs but would also invest in improving the 'employability' of those furthest from the labour market. This increase in labour supply would allow the economy to operate at a higher level of overall employment and output without creating inflationary pressures (Layard et al, 1991).

\section{The New Deals}

In a world of limited resources, Conservative spending plans, and four electoral defeats, New Labour's (1997) programme was cautious and targeted. The New Deal was to be financed through a $£ 5$ billion 'windfall tax' from the profits of privatised utilities. Top priority was given to the young unemployed, with the incoming Government pledged to finding jobs for 250,000 18 to 24 year olds who had been out of work for over six months. Within five years New Labour had developed a more comprehensive approach. By 2001 there were 'New Deals' for long-term unemployed adults aged over 25, lone parents, disabled people, those aged over 50 and the partners of unemployed people.

Although each New Deal addressed the particular problems of a specific client group all were based on the principles first implemented in the programme for young people "more help, more choices, and the support of a Personal Adviser .. matched by a greater responsibility on the part of individuals to help themselves” (DfEE, 2001, para 1.33). This focus on support tailored to the needs of each individual was the "key feature" that "distinguished it from previous initiatives" (Hasluck, 2001, p. 230). Despite the common framework, however, there continue to be significant differences in the level of resources allocated to each programme. Table 1 shows that the better funded New Deals are mandatory and are targeted at the registered (usually male) unemployed. Fewer resources have been allocated to the voluntary programmes aimed at the larger numbers of lone parents and those receiving disability benefits. 


\section{(Table 1 about here)}

\section{New Deals, Compulsion, Work Focused Interviews and Jobcentre Plus}

Participation in the New Deals for the registered unemployed commences with an advisory 'Gateway' process when a personal adviser helps tackle employment barriers and provides assistance with job search, careers advice and guidance. If an individual is unable to get an unsubsidised job they are required to participate in an employment or training option, which in the NDYP consists of:

- the Employment Option which provides a subsidised, waged job for six months with an employer;

- the Environmental Task Force (ETF) or Voluntary Sector Option which both provide up to six months employment in a job with a wage or, more often, a 'benefits plus £15' package; and

- the Full-time Education and Training Option (FTET) which can last for up to a year. Participants are paid an allowance equivalent to their benefits and have some access to expenses for exceptional costs.

All the options involve vocational training and there is a 'follow through' process of advice and support for those who do not get a job by the time they complete their option. By the end of 2001 more than three quarters of a million young people had 'entered' the programme. There were, however, only 80,500 active participants, of whom about $60 \%$ were in the Gateway.

Young people under 25 years are usually required to enter the New Deal after six months unemployment. For those over 25 years a minimal programme originally was targeted at those out of work for over two years. In April 2001 this was replaced by a more intensive programme, similar to that aimed at young people, and those out of work for over eighteen months must now participate or face the same benefit sanction regime which applies to the younger age group.

In practice unemployed people that do not comply with JSA or New Deal requirements can face sanctions that terminate all cash assistance. If an unemployed person is unavailable for work, or fails to attend a meeting with their Advisor or 'sign on' without good cause, they lose their entitlement to benefit. Alternatively an individual can lose their cash assistance for up to 26 weeks if they leave or are dismissed or refuse a job without good cause. An ES 'Decision Maker' determines the length of the penalty but it usually lasts the full 26 weeks. The penalties for not attending or being dismissed from a mandatory employment programme without good cause escalate from a two-week sanction for the first offence, to four weeks for the second time they break the rules and to 26 weeks for the third instance of non-compliance. Some specified groups can claim special hardship payments and Housing and Council Tax benefit is only withdrawn for the first type of sanction. 
Significantly, New Deal programmes for working age people who were previously regarded as 'economically inactive' are being implemented within a mandatory, 'rights and responsibilities', framework. The childless partners of unemployed claimants, who are aged between 18 and 24, are now required to register as unemployed and, when eligible, enter the New Deal. This requirement gradually is being extended to the childless partners of older unemployed people and the partners of people receiving other working age benefits. Participation in the less resource intensive New Deals for lone parents and for people with disabilities remains voluntary (at the time of writing), but these programmes now operate in a regulatory regime where working age people applying for and receiving state benefits are required to attend 'work focused interviews' (WFI).

This 'employment first' regime is being implemented by 'Jobcentre Plus'. The agency is expected to modernise service delivery, particularly through the use of computers, telephones and on line technologies. The aim is that by 2005 it will have fully integrated the work of ES and BA staff in 1,500 local offices. Jobcentre Plus offices are designed to reinforce the culture change. Largely open plan, they aim to deliver a 'queueless' professional service in a modern environment. The agency will be expected to process and pay benefits accurately and promptly, but the expectation is that those using its services will experience an 'employment first' approach. In Jobcentre Plus offices this will mean that a prospective claimant first will be seen by a 'benefit financial assessor', followed by a WFI with a personal adviser. The intention is to 'tackle' benefit related issues before the employment interview where an adviser will provide immediate job search advice, refer individuals to the various New Deals, and work with a small caseload of those who may be helped into work.

\section{The 'front line' experience of the New Deal}

The new 'employment first' regime is intended to change the experience of those who both work in and use Benefit Offices and Jobcentres. The model for this 'cultural revolution' has been the NDYP. The following sections draw on the findings from four 'front line' research projects which all explored what this change had meant in practice and the extent to which NDYP had reshaped daily interactions between front line staff and clients. The studies were carried out in Manchester, Portsmouth, London and Coventry, between 1999 and 2002. Two were independently funded and two were commissioned. Each involved interviews and focus groups with front line advisers, providers and young unemployed people. Through partnership work with the Centre for Economic and Social Inclusion the author was able to ensure that each project addressed the themes explored in this article. In Manchester focus groups were held with $40 \mathrm{New}$ Deal advisers and 30 young people, and most voluntary sector and environmental providers were interviewed (Finn and Simmonds, 2000). In Portsmouth interviews and focus groups were held with 30 advisers and providers, and with 23 young people (Finn and Blackmore, 2001). In London interviews were carried out with 33 advisers, 57 young people, and 12 option providers (CESI, 2001). Subsequently, interviews and focus groups were carried out with twenty advisers and providers and the same number of clients clients in London and Coventry (Perkins-Cohen, 2002). 
There are, of course, significant differences, between the case study areas. Those individuals interviewed also were not chosen randomly. In London, some young people were interviewed in the Gateway phase, but most of the interviews in each area were carried out with young people in the ETF and VSO. They represented those facing the greatest employment barriers. Over the research period there were also constant changes in programme regulations and, most significantly, in each area unemployment fell dramatically.

\section{The Gateway, Job Aspirations and Matching}

The initial Gateway combination of advice, support and 'pressure', has been seen as one of the most effective innovations in the programme (Millar, 2000). It is the New Deal experience for the two thirds of young people who leave the programme during this phase. The evaluation evidence shows a 'carrot and stick' effect, with most young people intensifying jobsearch as a result of increased motivation and new techniques, but others doing so in order to avoid joining an option or to avoid benefit sanctions (R\&DDES, 2000). 'Shaking the tree', as it has been described, has had an initial effect following the introduction of successive mandatory programmes. Nearly $10 \%$ of young unemployed people sent an initial letter sign off JSA before they attend their first interview; and about $60 \%$ of those who attend a first interview leave before entering an option. Over $40 \%$ of all Gateway leavers are known to enter unsubsidised jobs, just under 30\% enter other 'known destinations' (such as education or claiming another benefit), and nearly a third leave to an unknown destination (see below).

In the case study areas the front line staff confirmed that the assessment provided through the Gateway process enabled New Deal Personal Advisers (NDPAs) to offer advice and assistance that had not been available under the previous regime. At its best the NDPAs said they were able to provide a range of individualised services for the young person such as identifying barriers to work, helping with applications, contacting employers and discussing and clarifying employment goals. There was, however, some evidence that NDPAs worked most intensively with those who they thought were most 'job ready'. Many of the young people were appreciative of the support they were given (see also, Hasluck, 2001, p. 231). Some complained, however, that they were being 'pushed' into things. Others said there was little difference to 'signing on'. For one young man "the only difference is that I go up two extra flights of stairs”.

The aim of ‘joining up’ NDYP with other services to provide tailored support proved more difficult than anticipated. In each of the areas NDPAs acknowledged problems in making successful referrals to the other services needed by the most disadvantaged. In some cases local services were either unavailable or had long waiting lists. In other cases clients, and sometimes NDPAs, found it difficult to identify or tackle deep-seated barriers, especially literacy, numeracy, health and behavioural problems.

In all four areas the young people were clear that what they wanted out of the New Deal was a 'reasonable job'. This was generally defined as a job which would offer employment 
security and opportunities for enhancing skills and earning power. They strongly believed that they should be able to choose what work they did and should not be expected to take short term 'agency work' or any 'crap' job. The message was deceptively simple:

“No-one at this table wants to work at McDonald's, nobody here thinks “yes, I'd like a career at McDonald's".. If they were given the opportunity to do something in the areas that they want, then they'd take it ... Give people the opportunity to do something they are really good at rather than a crap job - then there'd be a rush to get off the dole."

There was little evidence, however, that the young unemployed were being compelled to take 'Micky Mouse' jobs in the 'contingent' labour market. Most of those we interviewed said that their advisers had listened to and taken their interests and career aims into account. While some had experienced 'pressure' to consider jobs they did not want, most criticism centred on how they were forced to join an option as the Gateway progressed. One common complaint was that the young people, who were by then in options, had not been asked about employment barriers or offered any vacancies before the Gateway.

Advisers themselves seemed keen to place young people in the jobs they wanted but were clear that not all clients could be effectively matched. A key part of their task was to tackle what were thought to be unrealistic expectations. There were also issues about the sectoral and geographical distribution of vacancies, sometimes exacerbated by the limited availability and expense of local transport and the 'walk to work' culture favoured by some.

Advisers aimed to persuade clients to expand the type of vacancies they would consider and to guide them about the importance of acquiring generic work experience to improve their employability. Whilst Advisers acknowledged putting 'pressure' on some young people to take jobs that they did not want they appreciated there was a limit to what they could achieve. Inappropriate matching or pressure could result in someone not turning up or simply leaving a job or option early. 'Agency jobs', which were abundant, were only thought appropriate in very limited circumstances.

During the fieldwork period there was evidence that, as the programme moved from its innovative phase to more routinised implementation, it was losing some of its distinctive features. Advisers pointed to several trends:

- they did not have enough time to do follow up with clients placed in jobs or options;

- too much time was absorbed by frequent changes in complex procedures and processes and by excessive paperwork; and

- their caseloads were difficult to manage as they contained a greater proportion of clients with complex employment barriers.

Most significantly there was concern that the individual focus of the New Deal had given way to an increased emphasis on placements, especially into unsubsidised jobs, driven by performance targets: 
'The message has changed now. We were trying to get at their issues, trying to understand their problems, build up the relationship, but that's gone now. They just want them off the register'. (NDPA, London)

\section{The 'hardest to place' and 'hard core'}

Most young people entering NDYP leave quickly, mainly into jobs. According to NDPAs, there were two groups however, that did not make a quick transition. One group, the 'hardest to place', often had significant employment barriers that could not be tackled during the Gateway phase and/or required other significant interventions. These included those clients without accommodation or those with debt or child support issues. There were also those with learning or behavioural problems unable to sustain the discipline required by regular attendance, and still others had barriers outside the advisers' expertise, such as mental health issues:

'We are not trained counsellors and we need to be for a lot of the people we see. We try but these people need specialist help and it isn’t always available locally'. (Manchester NDPA)

The other group often were characterised as the 'hard core'. This was made of up of two, sometimes overlapping, constituencies. There were the small but significant minority of individuals who were thought to be 'working the system'. Engaged in the informal economy, they supplemented their income through hidden employment, 'benefit surfing', and activities as diverse as 'booze running' or 'dealing'. The other constituency was associated with 'tough' estates, with deep antipathy to 'schemes' and 'skivvy labour':

'Most of our time is taken up dealing with the ten per cent hard core who are deliberately finding ways to beat the system and avoid being put through the programme'. (Portsmouth NDPA)

'Some of these clients are very wary, there is a lot of mistrust. The bulk of the problems now are because we are dealing with stock .. Some of these people are second and third generation unemployed and there are entrenched attitudes. In some places there is a benefit mentality .. they've been on the streets since they were 12 or 13 , so they are very wary'. (Manchester NDPA)

Advisers expressed frustration about the adverse impact of these clients on the advisers' ability to work with those more willing to engage with the process. Notwithstanding the controversial sanctions regime associated with the NDYP, the advisers remained sceptical about its power to change the behaviour of the 'hard core'.

\section{The Options: Employability or Work First}

The role of the options is to improve the employability of those young people who could not obtain unsubsidised jobs. The evidence on New Deal employment subsidies supports their value 
as an "effective way" of getting (both young and old) New Deal clients into "sustainable employment” (Hasluck, 2001, p. 233). The non-employer based options have, however, been criticised for not securing the level of job entries expected, with only about one on five leavers going directly into a job.

Providers attribute this to the fact that they have had to engage with clients who are significantly more disadvantaged than those who entered earlier programmes, and who had not been adequately prepared for work or for participation through the Gateway. Option providers reported particular problems with young people who were unmotivated, lacked social skills, had turbulent personal lives, and found it difficult to work with others. The attendance and timekeeping of this group was poor and in too many cases they would leave early or be dismissed. Despite these problems the providers we talked to were positive about the impact they could have through the New Deal:

'A lot of these New Dealers come here with a history of failure - and we can turn them round...we can't turn them all around, but we turn a good number around'. (Manchester ETF Provider)

The perceptions of the providers were borne out by the young people. Many of those on an option whom we interviewed agreed that taking part in the programme gave them routine and stability, helped increase self-esteem and confidence and they were hopeful participation would improve their job prospects. Levels of satisfaction were highest amongst those who were able to do something of interest to them. Most dissatisfaction was expressed by those who were forced to attend, especially on ETF placements. In Manchester, a focus group, composed of those required to participate, found high dissatisfaction with being forced to carry out unpleasant or dirty tasks (for example, washing floors in blocks of flats and picking up needles and nappies from the surrounding gardens). This group were highly negative, believing they were being 'punished' and so were highly critical of the New Deal:

'New Deal is a training scandal - it's a way of cutting down the numbers and getting you out of the way for six months...by that time other people are going to be slammed on it. It's just a way of making the Government look good.. "Oh look what the Government are doing. Look at our New Deal badges”’.

Many providers expressed concern that their capacity to convert such attitudes was being undermined by pressures to boost their employment outcomes. Some were concerned that linking more of their funding to job entry would lead to encouraging young people to take up less satisfactory job opportunities when they might gain more (in terms of longer term employability) from a longer period on their option. Others believed that the job entry focus was devaluing their success in improving life skills and motivation:

'What are the priorities of New Deal? It seems to be about targets for jobs and less about employability and a client centred approach. The Government needs to make up its mind. I’m getting mixed messages'. (VSO provider in Portsmouth) 
Advisers and option providers acknowledged that job entry was important, but emphasised that it should not be the only criterion on which their work is to be judged. They emphasised that some of the least employable young people made significant progress in the New Deal, without necessarily getting a job, and this had a social return as much as an economic one:

'Sometimes it's not the job that is the priority, because they've got so many other additional problems. For some its an achievement to get them to stay for the whole course .. If you look at how poor their record was before they started, the fact that they've lasted six months or a year is a real achievement'. (FTET provider)

'Jobs can't be the only test. We have helped change people's lives. .. It's very very difficult to show it. They might not move on into work but they've moved on. They've gained such a lot. They've got more confident. They are able to talk to other people. Its that kind of thing, and I don't think New Deal gets enough credit for that'. (ETF provider)

\section{The New Deal and Sanctions}

There has been much concern expressed about the impact of the New Deal sanctions regime. Initially NDYP operated within general JSA regulations but in March 2000 the regime was intensified and after a 'third offence' an individual may now have their benefit suspended for up to six months, following previous sanctions of two and then four weeks. The Social Security Advisory Committee (SSAC) expressed strong concern that although the severity of the sanction might be warranted for someone who deliberately flouted the rules, it "might unintentionally penalise a higher than expected number of other groups who, for a mixture of social, educational or health reasons, were unable to comply with the requirements of New Deal Options” (quoted by Britton, 2002, p. 12).

It is difficult to disentangle the extent to which young people have been sanctioned through the New Deal, but one estimate suggests that some $9 \%$ may experience a benefit reduction during the Gateway phase (Gray, 2001, p.378). During the option phase the evidence on sanctions is clearer and the rate at which sanctions have been imposed has increased, with over 3,000 reported in the last quarter of 2001 (TEN, 2002, p. 1). These sanctions are imposed for either failing to attend, or leaving options without good cause, and they are largely experienced by poorly educated and less motivated young men with regard to participation in the ETF (Bonjour et al, 2001, pp 112-115). Although the number who experience a third sanction is small, qualitative evaluation has shown that while some then obtain a job, a significant minority of vulnerable young people had, as predicted by SSAC, lost their benefits for six months and lost contact with services that should have assisted them (Saunders et al, 2001).

Notwithstanding the impact on some vulnerable young people the front line evidence from the case study areas depicts a more complex picture than that suggested by crude perceptions of a coercive authoritarian regime. Amongst the young people themselves there 
was a range of responses to the New Deal sanctions regime. While some resented their new responsibilities, most accepted that sanctions were justified either to put pressure on those not genuinely seeking work and/or to maintain discipline while participating in the programme. These comments were made by ETF participants of whom most had been required to join the New Deal:

'If you're constantly unemployed they have got a right to push you'.

'People should make the effort to work, not just sit around'.

'Sanctions are a fair way of stopping people from messing around. You have to have something otherwise people would just stop whenever they felt like it'.

'Sanctions are unfair, they're forcing you to do it...if you don't turn up they say they'll stop your money. It doesn't work .. (and, laughing) .. we're not forced to turn up'.

Most of the NDPAs agreed that sanctions were necessary both to test willingness to work and to convince young people that they should attend an option. They were, however, critical about the processes involved. In their view the sanctions regime was administratively complex, hard to implement, and generated a disproportionate amount of paperwork. The eventual outcome was often uncertain and if a sanction was overturned it significantly damaged their credibility with the client. Even when a sanction was imposed many clients could fall back on family or friends or claim 'hardship', so that in their view the actual penalty was minimal:

'Frankly, sanctions don't affect the hard core much because of hardship payments. Sanctions are more of an inconvenience than a deterrent - a slap on the wrist, and one that they seem to be able to accommodate quite comfortably'. (Portsmouth, NDPA)

This frustration with the sanctions regime was balanced by 'front line' concern with the counter-productive impact that a tougher regime could have. For example:

'I'm against imposing benefit sanctions because four months trust can go out the window .. I would prefer to use more intensive help'. (Manchester NDPA)

Advisers also wanted discretion. They wanted to be able to extend the Gateway rather than require a client to reluctantly join an option. Others complained of an absence of suitable placements for the hardest to help. In their view sanctions were too blunt an instrument to deal with individuals who might have chaotic lifestyles characterised by, for example, drug abuse and/or homelessness. There was a danger that the use of mandatory referrals merely shifted the problem cases onto option providers thereby exacerbating high drop out rates leading to the imposition of sanctions. 
Other front line providers were still more sceptical and worried that a harsher approach was liable to impact on those with certain disadvantages rather than on those who understood how to work the system. Some were concerned that there was a danger of stigmatising many young people who, given additional time and resources, could be 'turned around':

'I'm not always sure that those branded as 'hard core' or 'stroppy' etc., haven't got deep rooted problems that could be sorted out given more time and support'. (Portsmouth voluntary sector provider)

\section{Unknown Destinations}

About a third of the young people leaving the New Deal are categorised as entering an 'unknown destination'. In the case study areas it had been as high as 50\% at the start of the programme.

There are a variety of administrative and individual reasons for not capturing information on the destination of all New Deal leavers. These factors also limit the information available about all those who leave the benefit system, and have impacted on the data available on earlier employment programmes. This 'go away' effect has not previously been officially investigated but concern about this group prompted a large scale national follow up survey (O’Donnell, 2001). The response rate was just below $50 \%$ but the researchers suggested there was no discernible evidence that the most disadvantaged were disproportionately represented among those who could not be contacted. Of the sample contacted $56 \%$ had initially left the New Deal to enter employment and just over $5 \%$ reported that they had not been entitled to claim due to sanctions. Some had continued to 'sign on', others had been ill, and some had entered education or otherwise left the labour market. At the actual time of the survey the status of the young people had changed, with $43 \%$ reporting they were in work and 30\% claimant unemployed. The researchers also explored the experience of other barriers, and found that far fewer of those experiencing at least one of the living conditions associated with disadvantage (been in custody; slept rough; lived in a hostel/foyer; been in care) - less than $30 \%$ reported that they had left NDYP to enter full time employment.

The front line agencies we interviewed reported that there were issues - that some of their clients would not participate and others had been sanctioned - but that they had not experienced a 'surge' in cases, comparable to what happened when benefit entitlement was withdrawn from 16 and 17 year olds in 1988. They did stress, however, that it was 'early days', and the young people they worked with were only tentatively engaged with the labour market. The tendency for these young people to move in and out of jobs quickly and to engage intermittently with the New Deal made it likely that the disciplinary regime of the programme would exacerbate rather than help tackle their social exclusion.

This 'exclusion' is exacerbated by the way in which the New Deal is delivered. In particular, option providers are incentivised by contractual clauses to work with those who are closest to entering employment. There are few other incentives for 
providers to devote scarce resources on clients who are not job ready much less those who have failed to attend. It is not a deliberate act but the current system encourages providers to work with those who are most engaged with the programme and to overlook those who do not attend or who quietly disappear. Ignoring the 'no shows' defeats the purpose of mandatory employment assistance, and the current incentive structure fails to encourage providers to "attract, convince or cajole reticent clients, help them overcome their barriers to employment and find a good job” (Perkins-Cohen, 2002, p. 5).

\section{The employment impact of the New Deal}

At the end of 2000 the Labour Government claimed that it had assisted 250,000 young people into jobs through the NDYP (DfEE, 2000). A year later it was suggested that well over half a million people had found jobs through the various New Deals (see Table 1), and that some $53 \%$ of NDYP leavers were entering employment. Just under $80 \%$ of the jobs are 'sustained' for over 13 weeks. There is little information available about the quality of jobs entered but a national survey found high levels of job satisfaction amongst those in work 18 months after starting the programme and it reported some evidence of wage progression amongst those in employment (Bonjour et al, 2001).

The combination of employment growth and the New Deals has produced significant reductions in JSA unemployment, especially amongst the long term unemployed. The number of 18 to 24 year olds in GB who were out of work and claiming JSA for over 26 weeks (the point at which they enter the New Deal but are still receiving JSA) fell sharply from 66,638 to 35,061 , a fall of $47 \%$. The most dramatic impact was on those registered as unemployed for over a year, where the number fell from 46,629 to 4,130, a fall of over $90 \%$. The reduction in the shorter term unemployed was, however, less marked, with the number of those out of work for less than 26 weeks only falling some 6\%, from 216,514 in April 1998 to 204,273 in March 2002. There were some cyclical factors at work, with the inflow into unemployment increasing in early 2002, but this data reinforced concern that the NDYP might be 'recycling' the unemployed, rather than moving them directly into jobs.

Unfortunately, establishing the net additional employment impact of the NDYP is more complex. The most authoritative econometric findings come from evaluations carried out by the National Institute for Economic and Social Research (Anderton et al, 1999; Riley and Young, 2000) and the Institute for Fiscal Studies (Blundell, 2001). Both studies concluded there was a positive impact. The IFS found an "economically and statistically significant effect" on the flow of young men from JSA to employment (Blundell, 2001, p. 34). The NIESR findings, themselves independently scrutinised by the National Audit Office, concluded that on the evidence it was "reasonable" to conclude that in its first two years NDYP was cost effective and directly reduced levels of youth unemployment by between 25,000 and 45,000 and increased youth employment by between 8,000 and 20,000 (NAO, 2002, Part 3).

There have been less favourable assessments of the employment impact of the NDYP. Apart from those who suggest that the reduction in youth unemployment simply has reflected the 
strength of the economy, others point out that despite the reduction in long term youth unemployment about a third of those who participated in NDYP returned to unemployment and about one in five of those who did obtain a job failed to retain it for 13 weeks. Some of these young people are now entering the programme for a second or third time. This problem is most acute for young black people and for those in many inner urban and depressed industrial labour markets where, it is suggested, the concentrated geography of unemployment leads to the "recycling and churning" of participants and that local 'jobs gaps' have undermined the programme (Martin et al, 2001). In response, Government economists have argued that appropriate vacancies arise in most local labour markets and that participation has reduced the 'scarring' effect of long term unemployment with those reentering the programme exiting at the same rate as the newly unemployed rather than becoming 'detached' and entering long term unemployment (Wells, 2002). In its 'Next Phase' of the New Deal the Government has responded by increasing efforts to achieve 'parity' of employment outcomes for ethnic minorities and introducing 'Step Up', a temporary job creation programme targeted at high unemployment areas and aimed at those who fail to get unsubsidised jobs after participation in the New Deal (DWP, 2001).

The 'net' employment outcomes of the NDYP continue to be contested and the detailed evaluation results for the other evolving welfare to work programmes, especially for lone parents and the older unemployed, have also been challenged. Nevertheless, the balance of the evidence supports the conclusion that the strategy is accelerating the return to work, especially of the long term unemployed, and that it is contributing at least some net increase in employment (Blundell, 2001). What is less clear, however, is that the positive impacts associated with the NDYP and other programmes will be sustained as more people pass through the various New Deals and as front line staff grapple with the administrative challenge of implementing an 'employment first' regime.

\section{Conclusion}

This article has illustrated that the NDYP has within it multiple, sometimes contending, objectives aimed at promoting labour market efficiency, controlling benefit payments, and enhancing the welfare of individual unemployed people. At the front line the programme seems far more complex than the monolithic instrument of social control suggested by some social theorists and critics. There are many problems with the NDYP, but there has been progress in improving the quality of service available for the young long term unemployed and in accelerating their entry into work.

There is nonetheless an acute tension between the increased pressure to secure immediate job entries and the capacity to improve the longer term employability of those furthest from the labour market. These mundane, practical issues of administrative reform and implementation are complex, but are assuming even greater significance as Jobcentre Plus creates the new 'employment first' welfare regime. Other types of employment assistance may be needed for those who fail to get work, and other types of activity and support will be needed for those who are unable to work either in the short or longer term. Jobcentre Plus will have to generate the skills and broader networks needed to tackle individual and collective employment barriers, while simultaneously ensuring that 
benefits are accurately assessed and promptly paid. Rebalancing rights and responsibilities may encourage those who can to become self sufficient, but it needs new checks and balances to ensure that vulnerable people are not denied access to the financial support and services they need. Generating solutions to these challenges can best be assisted by a social policy debate that engages with and informs practice rather than retreats from it. 
Table 1: New Deal Employment Programmes

\section{Start \\ Date \\ Estimated Cost \\ (Em 1997-03)}

April 1998

June 1998

October 1998340

New Deal for Disabled

People

April 1999

165

65

of the Unemployed April 1999

April 2000

1,470

640

New Deal for People

aged 50 Plus

65
353,300

62,410

$305,030 \quad 127,920$

(joined

caseload)

20,000

8,000

(to June 2001)

$\mathrm{n} / \mathrm{a}$

$\mathrm{n} / \mathrm{a}$

$\mathrm{n} / \mathrm{a}$

$\mathrm{n} / \mathrm{a}$

Sources: Figures taken from Table 4.1, Pre Budget 2001 report and show planned Windfall Tax expenditure on the New Deal, HMT 2001. Data on NDDP participants and job entries from HMT, 2001, p.29. Source for Participants and Job Entry on other New Deals: unpublished performance papers given to the New Deal National Employers Panel Performance Sub Group, February 2002. 


\section{References}

Anderton B., Riley R. and Young G. (2000) New Deal for Young People: First Year Analysis of Implications for the Macroeconomy, Employment Service, Research and Development Report, ESR 33, Sheffield.

Blundell R. (2001) Welfare to Work: Which Policies Work and Why?, Keynes Lectures in Economics, University College and Institute for Fiscal Studies: London.

Bonjour D., Dorsett R., Knight G., Lissenburgh S., Mukherjee A., Payne J., Range M., Urwin P. and White M. (2001) New Deal for Young People: National Survey of Participants: Stage 2, Employment Service Research and Development Report, ESR 45, Sheffield.

Britton L. (2002) 'Sanctions and the hard to help', Working Brief, January, pp 12-14, Centre for Economic and Social Inclusion, London.

CESI (2001) Job Retention and Upskilling in the NDYP, unpublished report for London \& South East Region of the Employment Service, Centre for Economic and

Social Inclusion, London.

DfEE (2000) New Deal Facts and the Future: 250,000 off welfare and into work, Department for Education and Employment, London.

DfEE (2001) Toward full employment in a modern society, Secretary of State for Education and Employment, Cm 5084, the Stationery Office, London.

DWP (2001) New Deal: Next Phase - Towards Full Employment in a Modern Society, Employment Service, Part of the Department for Work and Pensions: London.

EC (2000) Employment Policies in the EU and in the Member States: Joint Report, Employment and Social Affairs, European Commission: Brussels.

Finn D. and Blackmore M. (2001)Next Steps for Welfare Reform: Lessons from the New Deal for the Young Unemployed in Portsmouth, University: Portsmouth.

Finn D. and Simmonds D. (2000) Improving the New Deal: Community and Environmental Employment Across City Pride (Manchester, Salford, Tameside and Trafford), Employment and Regeneration Partnership, Manchester

Giddens A. (1998) The Third Way: the Renewal of Social Democracy, Polity Press: Cambridge.

GMLPU (1999) Rhetoric and Reality: Young People and the New Deal, Greater Manchester Low Pay Unit.

Gray A. (2001) 'We Want Good Jobs and More Pay’: A Participants' Perspective on the New Deal, in Competition and Change, Vol. 5, No. 4, Harwood Academic Publishers, Tay;lor and Francis: Hampshire pp 375-393

Green D. (1999) An End to Welfare Rights: The Rediscovery of Independence, Institute of Economic Affairs, London.

Hasluck C. (2001) 'Lessons from the New Deal: Finding work, promoting employability' in New Economy ???, pp 230-234,

HMT (2001) The changing welfare state: employment opportunity for all, HM Treasury and Department for Work and Pensions: London

Jeffs T. and Spence J. (2000) 'New Deal for Young People: Good deal or poor deal', Youth and Policy, No. 66 pp 34-62, Youth Work Press, National Youth Agency: Leicester

Jessop B. (1994) 'Post-Fordism and the state', in Post Fordism: A Reader, (ed) Amin 
A., Blackwell, Oxford.

Layard R., Nickell S. and Jackman? (1991) Unemployment: Macroeconomic

Performance

and the Labour Market, University Press: Oxford.

Martin R., Nativel C. and Sunley P. ((2001) 'Mapping the New Deal: Local Disparotoes in the Performance of Welfare-to-Work', Transactions of the Institute of British Geographers, Vol. 26 No. 4, pp 484-512.

Millar J. (2000) Keeping track of welfare reform: The New Deal programmes, Rowntree Foundation, York Publishing Services.

NAO (2002) The New Deal for Young People, Report by the Comptroller and Auditor General, National Audit Office: London.

O’Donnell K. (2001) New Deal Survey of Leavers to Unknown Destinations, ORC International, Employment Service Research and Development Report, ESR63, Sheffield.

OECD (1994) The OECD Jobs Study: Evidence and Explanation, Organisation for Economic Cooperation and Development, Paris.

Peck J. (2001) Workfare States, Guildford Publications:: New York.

Perkins-Cohen J. (2002) What to do When the Client's Don't Show: 10 Ideas to Improve Participation in Welfare to Work programs, Atlantic Fellowships in Public Policy, Foreign and Commonwealth Office, London.

R\&DDES (2000) What Works: Evidence from New Deal for Young People, Research and Development Branch of the Employment Service, unpublished paper given at the UK/US Symposium on Welfare to Work: New Solutions for the New Economy, 20-21 July, Windsor.

Riley R and Young G (2000) The New Deal for Young People: Implications for

Employment and the Public Finances, National Institute for Social and Economic Research, Employment Service Research and Development Report, ESR 62, Sheffield.

Saunders T., Stone V. and Candy C. (2001) The Impact of the 26 Week Sanctioning Regime, Employment Service, Research and Development Report, ESR 100, Sheffield.

TEN (2002) 'New Deal Sanctions', in Welfare to Work Briefing, No. 182, $11^{\text {th }}$ February, Training and Employment Network: London.

Tonge J. (1999) 'New packaging, old deal? New labour and employment policy innovation', in Critical Social Policy, vo l. 19, no. 2, Sage, London.

Wells B. (2002) 'Worklessness and Deprived Areas: What's the problem?', contribution to plenary session at joint Department of Work and Pensions, Treasury and Neighbourhood Renewal Unit, conference on How Can Policies on Labour Markets and Neighbourhood Renewal Best Work Together?, $10^{\text {th }}$ May: London 